\title{
Articles
}

\section{Activation Changes of Hafnia alvei Aspartase by Acetic Anhydride}

\author{
Im-Joung La, Joungmok Kim, Jeong-Rim Kim, \\ Ki-Tac Kim, Jung-Sung Kim, and Moon-Young Yoon ${ }^{\circ}$

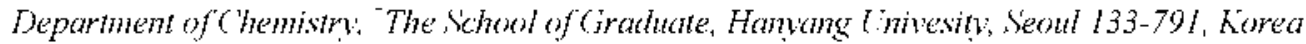

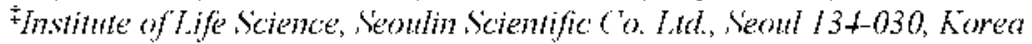

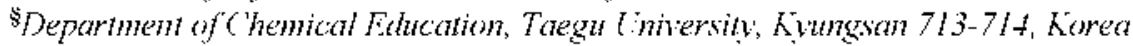 \\ Receried March 7, 2002
}

\begin{abstract}
The Hafina alvei aspartase activity with acetic anhydride treatment gradually increased and rached 7.5 -fold that of the native one. The activity of the acety lated aspartase was a little higher than that of the native enzzme. indicating that the cooperativity between a substrate and enzyme is increased. The optimum temperature of the native asparatse was $45^{\circ} \mathrm{C}$. and that of the acety lated enzy me shifted to $40^{\circ} \mathrm{C}$. The $\mathrm{pH} \mathrm{vs}$. the activity profile of the acetylated asparatse was also different from that of the native enzy me. The initial velocity pattern of the acetylated aspartase intersects to the left of the ordinate, indicating the sequential kinetic mechanism other than a rapid equilibrium ordered one. The reciprocal plots for aspartate of the native aspartase were curved. but those of the acetylated aspartase were linear. indicating the Michaelis-Menten kinetics. The helical content of the acety lated aspartase was rather decreased to $9 \%$ than that $(63 \%)$ of the native one.
\end{abstract}

Key words : Aspartase. Hafina ahei. Chemical modification

\section{Introduction}

Aspartase (L-aspartate ammonia-lyase. EC4.3.1,1) cataly/ss the reversible conversion of $\mathrm{L}$-aspastcatc to fumarate and an ammonium ion in the following reversible reaction. ${ }^{\prime}$

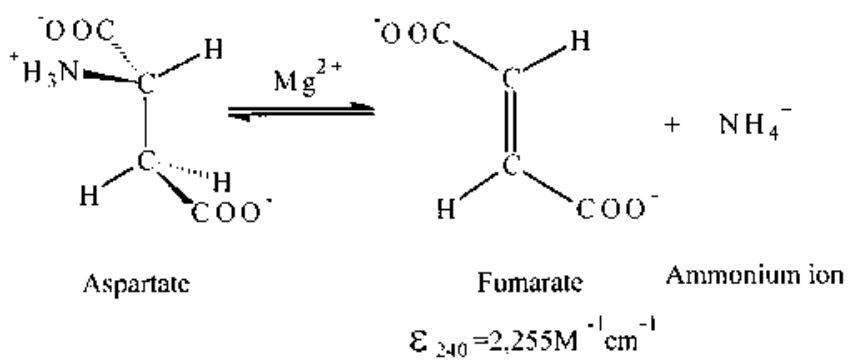

The aspartase is a tetramer composed of four apparently identical subunits of molecular weight 48.000 . The cnsyme was observed to have an absolute requirement for a divalent metal ion activator at higher $\mathrm{pH}$. with some indication that aspartase may possess some activity in the absence of the divalent metal ion at low $\mathrm{pH}^{2}{ }^{2}$ Nuiry, et at. (1984) carricd out a complete kinetic mechanisn study. which included a divalent metal ion as a pscudo - rcactant utilizing an initial velocity study. and the printary and sccondary kinctic isotope effects for aspartasc. ${ }^{3}$ Initial velocity data for Hafnica atvel asparase are consistent wilh a rapid cquilibrium ordered kinetic mechanism. caused by the ordered addition of $\mathrm{Mg}^{2-}$ prior to aspartate. followed by the completely random release of $\mathrm{Mg}^{2} \cdot \mathrm{NH}^{+}$or funaratc.

\footnotetext{
*Io whom comespondence should le addressed. Te]: $+82-2-2290$ 0946: Fax: +82-2-2299-0762: F-mail: myoondianyang.ackr
}

Accly lation on E. coll aspartase with acctic anhy dride and $\mathrm{N}$-hydroxy succinimide csters resulted in the alteration of its catalytic and regulatory propertics. ${ }^{+}$The two-fold activation at $\mathrm{pH} 7.0$ was observed for $30 \mathrm{~min}$. whereas the activity of the acclylated cnsme at $\mathrm{pH} 8.5$ was lower than that of the native enryme throughout the range of substrate concentrations tested. while maintaining the $V_{\text {max }}$ unchanged. The requirement of divalent metal ion for the ensme activity increased at both $\mathrm{pH} 7,0$ and 8.5 . In the metal-activity relationship before and after acclylation. the ratio of activity in the presence of $\mathrm{Mg}^{2}$ to that in its absence increased upon accly lation from 1.4 to 2.1 at $\mathrm{pH} 7.0$ and from 4.8 to 84.5 at $\mathrm{pH} 8.5$. The acetylated coryme at $\mathrm{pH} 8.5$ has very little activity in the absence of $\mathrm{Mg}^{21}$. Acctylation of the ensme with other acid anhydrides such as n-bulyric and propionic anhydrides also increased the activity at $\mathrm{pH} 7.0$. albeil to a lesser extent.

As industrial use of aspartase is increasing. some researchers have focused on the structure-function relationship for the activation of asparatse. ${ }^{5-11}$ In an effort to clucidate the nature of a more structure-function relationship of the accly lation in the aspartase reaction. we have tricd to investigate the activation with limited treatment of the acetic anhydride on aspartase from Hofnia alvet. In this paper. the effects of acety lation on the structure and the function propertics of Hofhia atvet aspartasc. as well as some propertics of the acctic anhydrideactivated aspartase are described.

\section{Material and Methods}

Chemicals. Hofnia alvei (ATCC 9760) was purchased 
from ATCC (American Type Culture Collection Rockville. USA). 2 -Hydroxychy lmercaptan ( $\beta$-Mcrcaptocthanol). Polassium phosphatc. Tris (hydroxymethyl) aminomethane. L-Aspartic acid and acetic anhydride were purchased from Sigma Chemical Co. (S1. Louis. USA). Magnesium chloride was obtained fron Yakuri Chemical Co. (Osaka. Japan). All other chemicals were obtained from commercially available sources and were pure or extra-pure for the available analy tical grade.

Enzyme Preparations. Asparlase was purified from Hafnia ahei as described by Yoon, et al. (1998) . 'ं Briefly, aspartase was oblained from a combination of DEAE-cellulose. Red A-agarose. and Scpharose 6B chromatography. The purificd ensme was divided into aliquots and stored at $-70^{\circ} \mathrm{C}$ until used. The activity of the ensyme remained stable for at least one month at 4 " $\mathrm{C}$ without appreciable loss of ensymatic activity. Protein concentration was determined by Bradfords method. The ensyme preparations used in this investigation were homogencous as judged by ultracentrifugation and poly acry lamide gel clectrophoresis.

Enzyme Assays. The activity of aspartase was deternined using a Hewletl-Packard 8452 Diode-Array spectrophotometer equipped with the constant-temperature $\left(25^{\circ} \mathrm{C}\right)$ cell housing. All reactions were carried out in $1 \mathrm{ml}$ curclles with a $1 \mathrm{~cm}$ light path length. which were incubated for at least 10 minutes in the cell compartment prior to the initiation of a reaction by the addition of aspartase. The progress of the reactions was determined spectrophotometrically and monitored continuously by measuring the lormation of fumarate by following the increase in absorbance at $240 \mathrm{~nm}$ $\left(\varepsilon_{200}=2.255 \mathrm{M}^{-1} \mathrm{~cm}^{-1}\right)$ at $40^{\circ} \mathrm{C}$. The standard assay mixture contained. in a total volume of $1.0 \mathrm{~mL}$ curctle. $100 \mathrm{mM}$ Tris- $\mathrm{HCl}$ buffer. $\mathrm{l}\left(0 \mathrm{mM}\right.$ aspartate and $4 \mathrm{mM} \mathrm{M \textrm {g } ^ { 2 }}$. $\mathrm{pH} 7.85$ and was incubated for 10 minules in a compartment. The aspartate and $\mathrm{Mg}^{21}$ concentrations were corrected for complcxation with a divalent metal using the following dissociation constant obtained at $0.1 \mathrm{mM}$ ionic strength: $\mathrm{Mg}-$ aspartatc. $4 \mathrm{mM}^{10}$ All other chemicals were also corrected for the metal-chelating effect. The reactions were started by adding appropriate volumes of the acetylated enzyme solution. The increase of absorbance at $240 \mathrm{~nm}$ that corresponded to fumarate formation was measured. The $\mathrm{pH}$ was recorded before and after the initial velocity data were recorded.

Acetylation Treatment. Aspartase was incubated with acetic anlydride at $0^{\circ} \mathrm{C}$. In $1.5 \mathrm{~mL}$ cuvette. $100 \mathrm{mM}$ phosphate buffer $5 \mathrm{mM} \beta$-mercaptoethanol. and various concentrations of acetic anhydride were prepared in a compartment. The reaction mixture contained $17.3 \mu \mathrm{g}$ of aspartase and incubated for a designated time at $\mathrm{pH} 7.3$.

Initial Velocity Study. The conditions of the initial velocity patterns for Hafnia ahei aspartase in the direction of the aspartate deamination reaction at $\mathrm{pH} 7.8$ were the same as those of the enzyme assay condition described previously. with various concentrations of aspartate and $\mathrm{Mg}^{3+}$. The various concentrations of substrates around $K_{n \mathrm{n}}$ were corrected for the $\mathrm{Mg}$-aspartate complex. The kinetic parameters for the enzymes were obtained using Cleland's Method of Net Rate constants (1979). ${ }^{14}$

Circular Dichroism. Circular dichroism (CD) spectra werc obtained on a Jovin-Yvan CD6 CD-ORD spectropolarimeter. Samples were contained in a quart\% curctte able to hold a volume of as much as $50 \mu \mathrm{L}$. All lar-UV spectra were scanned from 250 to $190 \mathrm{~nm}$ with a protein concentration of $0.5 \mathrm{mg} / \mathrm{mL}$ at intervals of $1 \mathrm{~nm}$. The sample bulter was 10 $\mathrm{mM}$ phosphate bulfer. pH 7.3. Each spectrum was composed of an ascrage of threc scans. The sample spectra were corrected by subtracting the appropriate bulfer blanks. The

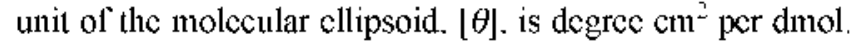
Values in degree were converted to rad. in order to compare then with the poly-L-lysine relerence data in yiclding the percentage of $\alpha$-helix. $\beta$-shect and random coil.

Other Determinations. In order to determine whether the optimum $\mathrm{pH}$ and temperature had been changed by the limited acetic anhydride treatment. $\mathrm{pH}$ and temperalure is. the activity profiles were compared before and after the acclic antydride treatment. The $\mathrm{pH}$ and temperature dependence of the activity of acctylated aspartase were carricd out according to the method of the cmsme assay as described previously (bide ante). The $\mathrm{pH}$ was maintained using the following buffers at $100 \mathrm{mM}$ concentrations: Hepes. 6.5-8.5: Ches. 8.5-9.0.

Data Processing. Reciprocal values of the initial velocitics were plotted as a function of the reciprocal of the substrate concentrations. All data were fitted using the computer program designed by Cleland (1979). converted to BASIC. and adapted for use on a microcomputer. ${ }^{1+}$ The modified ensyme plots were lincar. however. the native one showing the curvalure which has positive cooperativity. The initial vclocity patterns werc obtained by a least square method to the double reciprocal transformation. and data from the Dixon plot analysis were fitted using. Eq. (l).

$$
v=V A /(K \cdot A)
$$

Data for the initial velocity patterns in the direction of aspartate deamination were fitted line by line to Eq. (2).

$$
\text { v } V A^{2} /\left(a+2 b A+A^{2}\right)
$$

In Eqs. (1) and (2). A is the reactant concentrations, $V$ is the maximum velocity, and $K$ is the Michaelis constant for the varied substrate.

\section{Results and Discussion}

Effect of Acetic Anhydride Treatrment on Aspartase Activity. When aspartase was incubated with acetic anlydride at $\mathrm{pH}$ 7.3 and $0^{\circ} \mathrm{C}$. the enz me activity increased to the maximum and decreased gradually after transient. and reached rapidly to complete inactivation (data not shown). With $10 \mathrm{mM}$ acetic anhydride the activity of acetylated aspartase gradually increased and reached 7.5-fold that of the native aspartase after $10 \mathrm{~min}$ of incubation time (Figure 1). When the molar ratio of the acetic anlyydride to amino groups of the enzzme was $10^{4}$. the degree of activation was the highest under the experimental condition. The required time to reach the 


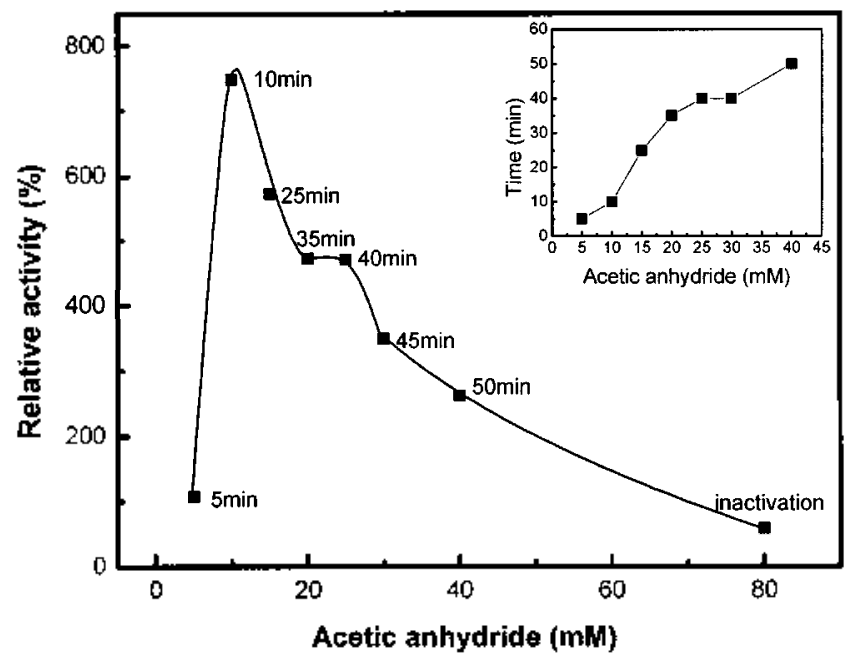

Figure 1. Lillect of acetic anhydride treatment on aspartabe activity. 'The reaction mixture contained $100 \mathrm{mM}$ polassium phosphate buffer, $\mathrm{pH} 7.3,5 \mathrm{mM} \beta$-1nercatoethanol. 17.3 $\mu$ o of aspartase and $20 \mathrm{mM}$ acetic anlyydride in a total volume of $0.5 \mathrm{mI}$. At designed time intervals. aliquots of the reaction misture were removed and analy $\angle 2$ dor myłme activily. The unsel shows the time change as a function of acetic anhydride concentration.

maximum level of aclivity of acelylated aspartase was increased along with the incrcasing concentration of acclic anhydride tested (Figure l. insel). The activation of the ensme decreased to complete inactivation alter increasing to the maximum. The low concentrations of acclic anhydride. from 0 to $+\mathrm{mM}$. showed no effects of acliyation. The Laspartate saturation profiles of aspartase before and aficr the acelic anhydride treatment were performod (data not shown). The activity of the acelylated aspartase was a little higher than that of the native ensme. indicating that the cooperativity between a substrate and ensyme is increased.

Optimum Temperature and $\mathrm{pH}$ of Acetylated Aspartase. In order to detemine whether or not the optimum temperature and $\mathrm{pH}$ of the acetylated aspartase had changed. the relative activities of the native and the acetylated aspartase were determined. Temperature dependence of the relative activity of the acetylated aspartase was bell-shaped. in the range of $20^{\circ} \mathrm{C}$ and $60^{\circ} \mathrm{C}$. similar to the native enzyme (Figure $2 \mathrm{~A}$ ). The native aspartase had an optimum temperature of $45^{\circ} \mathrm{C}$. However, the acetylated aspartase had a lower optimum temperature of $40^{\circ} \mathrm{C}$ and was less stable at ligher temperature $\left(\geq 45^{\circ} \mathrm{C}\right)$. The maximum relative activities of the acetylated and the native aspartase were almost the same. Optimum $\mathrm{pH}$ levels of the acetylated and the native aspartase were 7.85 and 8.5 , respectively (Figure $2 \mathrm{~B}$ ). The relative activity difference between the native and the acety lated aspartase at the optimm temperature and $\mathrm{pH}$ was $20 \%$ and $30 \%$. respectively.

Initial Velocity Pattern of Acetylated Aspartase. In order to examine whether or not the functional alteration induced by acetylation involves any kinetic influence the initial velocity patterns of the native and the acetylated aspartase were determined. The initial velocity pattern of the
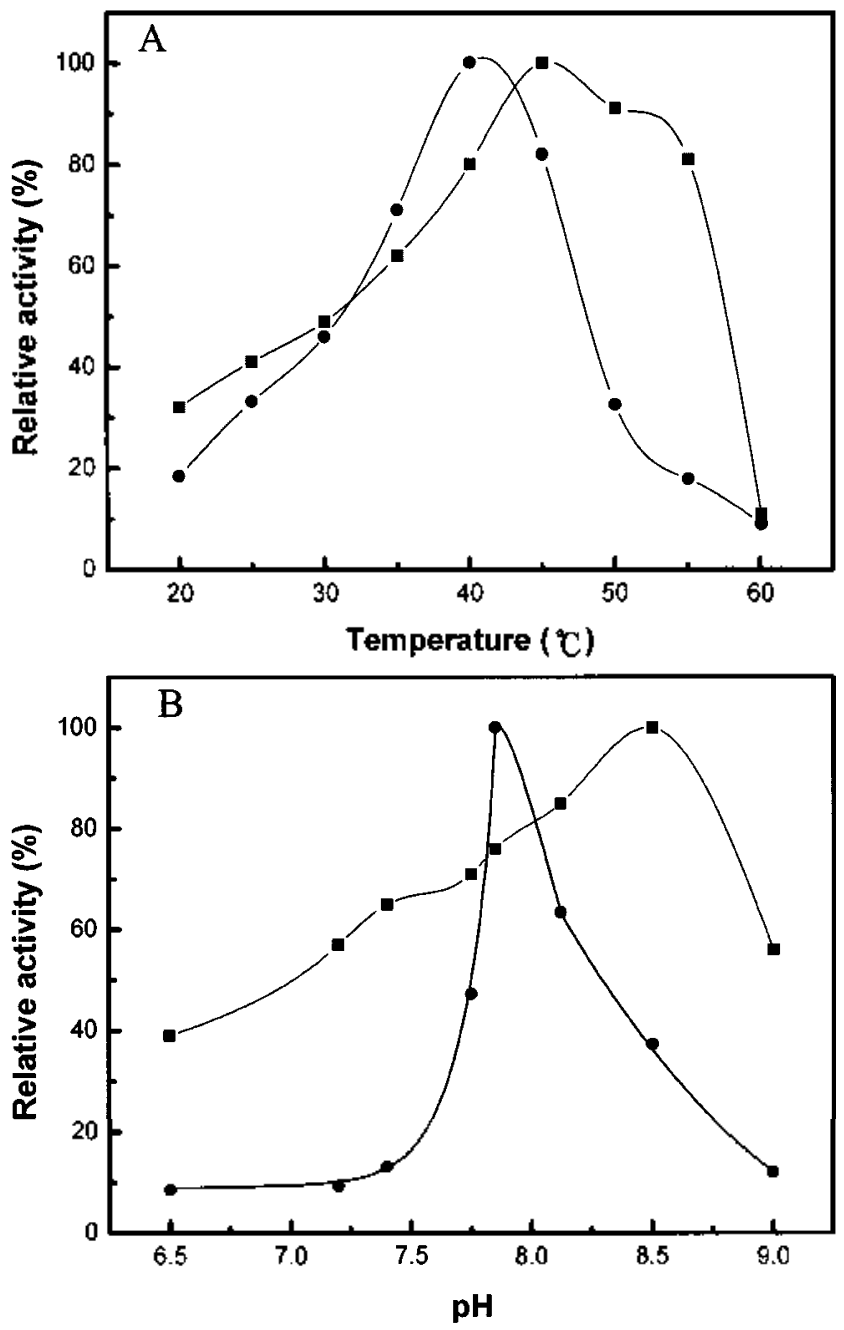

Figure 2. Optimum temperature $(A)$ and $\mathrm{pH}(\mathrm{B})$ of the native and the acety lated aspartase. The reaction misture at $400^{\circ} \mathrm{C}$ contained 10 $\mathrm{mM}$ aspartate, $100 \mathrm{mM}$ polassium phosphale bulier at $\mathrm{pH} 7.85$, acely lated ( $)$ or native ( $\left(\mathbf{a}\right.$ ) my me $(1.2 \mu \mathrm{g})$, and $4 \mathrm{mM} \mathrm{MgCl} l_{2}$ in the total volume of $1.0 \mathrm{mI}$. All substrate concentrations were corrected for the amount of metal chelate complex fomation as described under Matcrials and Methods.

acetylated aspartase was different from that of the native enzyme. When uncomplexed aspartate was varied at different fixed levels of uncomplexed $\mathrm{Mg}^{2+}$. the initial velocity pattenis were obtained. The initial velocity patterns of the native enzyme intersected on the ordinate, indicating the mechanism is the rapid equilibrium ordered addition of $\mathrm{Mg}^{2+}$ prior to aspartate (Figure $3 \mathrm{~A}$ ). However. the initial velocity pattern of the acetrlated aspartase intersected to the left of the ordinate. indicating that the mechanism is a sequential kinetic mechanism. not including a rapid equilibrium order mechanism. The $K_{m}$ and $V_{m(x)}$ values of the acetylated aspartase were significantly different from those of the native enzzine. In the values of the kinetic parameters for the acetylated aspartase obtained in the direction of aspartate deanination. the $K_{m}$ of the aspartate and $V_{\max }$ values were $1.07 \mathrm{nIM}$ and $7.24 \times 10^{-2} \mu \mathrm{mol} / \mathrm{min}$, respectively. The $K_{m}$ value of aspartate of the acetylated aspartase was smaller than that of the native 


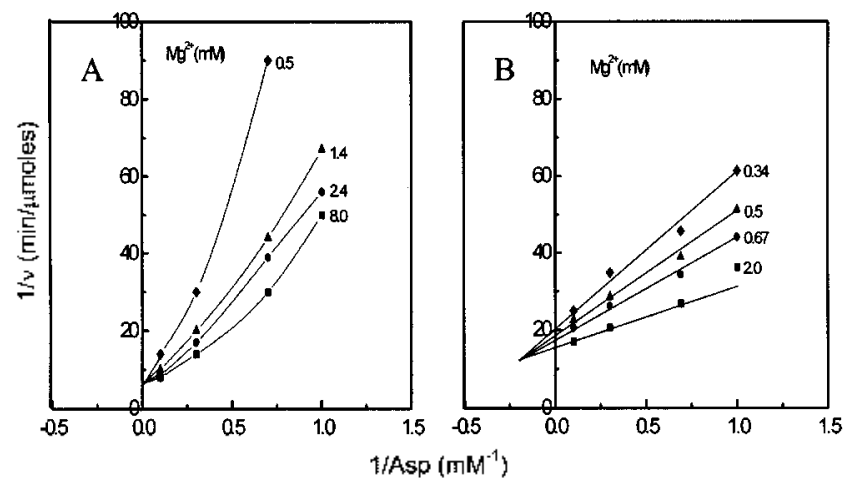

Figure 3. Initial velocity patterns for the native $(\Lambda)$ and the acetylated $(B)$ aspartase at $\mathrm{pH} 7.85$. All substrate concentrations "wre conected for the amount of metal chelate complex fonmation as described under Materials and Methods. The data were litted to F.?. (2).

aspartase $(2.5 \mathrm{mM})$ and the magnitude of $V_{\text {m:ax }}$ of the acely lated ens me was larger than that of the native cnsme $\left(2.5 \times 10^{-3}\right.$ $\mu \mathrm{mol} / \mathrm{min})$. The $K_{m}(2.1 \mathrm{mM})$ of $\mathrm{Mg}^{21}$ of the acclylated aspartase was larger than that of the native enryme (1.05 $\mathrm{mM}$ ). These results indicate that the accly lated aspartase has higher catalytic efliciencies. a measure of substrate allinity and product relcasing for substrates.

Circular Dichroism Spectra. In order to cxamine whether or not the acelylation of asparlase involves any conformational alteration. the conformational changes of the native and the acetylated aspartase were determined using a CD-ORD spectra (Figure 4). The secondary structures between the native and the acety lated aspartase were different in the values of threc basic categories: $\alpha$-helix. $\beta$-strand (oflen associated with socalled "shects"). and random coil. The acctylated aspartase exhibited negative cotton effects through $210 \mathrm{~nm}$ and 218 nnm. From these values. the pereentage of $\alpha$-helix structure

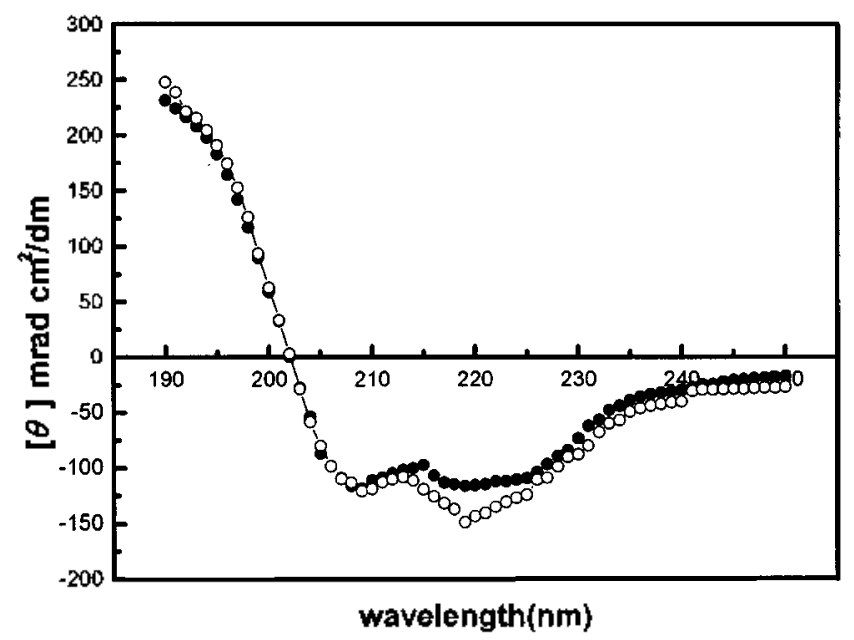

Figure 4. Circulat dichroism spectra of the native and the acelylated asparlase. The CD spectra of the native (-) and the acelylated (O) aspartase were measured at $25^{\circ} \mathrm{C}$ in a Jovin Yvan CD6 CD-ORD spectropolarimeter with a 0.1 cul light path. The experiments were perfonmed as described under Materials and Methods. The three determinations were oblained using new stock solutions. of the acetylated aspartase was $54 \%$ and that of the native cn:yme was $61 \%$, taking that of poly-L-ly sine as the standard $(100 \%)$. The amount of $\alpha$-helix of native aspartase from $E$. coll was estimated to be $60 \% .^{15}$ The spectra for the two Hafinia alve aspartase between the native and the acetylated aspartase cxhibited no signilicant dilference. However. the helical content of acetylated aspartase is about $7 \%$ less than that of the native aspartase. In addition. the percentage of its shect structure was increased from $23 \%$ (native) to $20 \%$ (acetylated).

\section{Discussion}

The ellects of various chemical modilications on ensmatic propertics have been widely cmployed as a useful technique for the investigation of the structure-liunction relationships among various enzymes. The most frequent consequence of chemical modilication of aspartase is inactivation. 16.17.18.19 The Hathia atvei aspartase was unexpectedly 7.5 -fold activated by the limited treatment of acetic anhydride. Howcver. the low concentrations $(\leq+\mathrm{mM})$ of acctic anhy dride had no eflects of activation. and the activation of aspartase by a certain variation $(80 \mathrm{mM})$ of the molar excess of acctic anhydride was decreased to complete inactivation. The activating effect of acelic anhydride on aspartase may be ascribed to the conformational change brought about by the modilication of amino groups (vide infra). Several other mono carboxylic acid anhydrides and $\mathrm{N}$-hydroxysuccimide esters have also been used as acylating agents under conditions identical to those for the acetylation of aspartase from 1: Colt. However. the magnitude of the increases in activity of these acylated aspartase species is less than that of the acely lated aspartase under these cxperimental conditions. ${ }^{+}$

Upon activation. temperature ss. the activity profile of the acclylated aspartase was essentially changed in comparison with the native aspartase. The optimum temperature of the native aspartase was $45^{\circ} \mathrm{C}$. and that of the acelylated enzyme shifted to 40 " $\mathrm{C}$. The $\mathrm{pH}$ vs. the activity profile of the acetylated aspartase was also different from that of the native enzyme. The optimum value of $\mathrm{pH}$ of the native aspartase was 8.5 and that of the modified enzyme shifted to 7.85. Concerning all these data. temperature and $\mathrm{pH}$ vs. the activity profile of aspartase were affected by acetylation with acetic anhydride, and the acetylated enzyme is a more sensitive molecular species, distinct fron the native enzyne. In addition. the activity of the acety lated aspartase was more sensitive to $\mathrm{pH}$ values than that of the native aspartase.

The initial velocity patten of the native aspartase observed when uncomplexed aspartate is varied at several fixed concentrations of uncomplexed $\mathrm{Mg}^{2+}$ intersects on the ordinate. indicating a rapid equilibrium ordered addition of $\mathrm{Mg}^{2-}$ prior to aspartate. However, the initial velocity pattern of the acetrlated aspartase observed under the same conditions intersects to the left of the ordinate. indicating the sequential kinetic mechanism, other then a rapid equilibrium ordered one. These results suggest that the conformational clange of aspartase by acetylation induced by the change of the 
substrate binding and the central complex (i.e. E-Mg-aspartate $\leftrightarrow$ E-Mg-fumaratc) is not a slow step. The reciprocal plots for aspartate of the native aspartase were cursed. indicative of positive cooperativity. but those of the acelvlated asparlase were linear. indicatise of Michaclis-Menten kinetics.

The helical content of the acelylated and the native aspartase were 54 and 63\%. respectively. Yoon. et al. (1998) estimated the amount of $\alpha$-helix of native aspartase from Hofina atve to be $61 \%$. which is almost the same value as our results. ${ }^{12}$ The helical content was rather decreased by the limited modification of acetylation with acctic anhydride. If this change caused the activation of aspartase. the acetylated activation is assumed to mediatc a conformational change of the individual subunits. On the basis of these observations. we would suggest that the activating effect of acetic anhydride on Hafina atrie aspartase is ascribed to a conformational change of the individual subunits because of a stoichiometric relationship between the corporation of acetic anhydride to the ensyme and the decrease of the percentage of $\alpha$-helix of the ensyme upon acety lation.

Among the attempts made in our laboratory. a covalent type activation of the ensyme was attained by a limited protcolysis with trypsin. The polypeptide chain of the native aspartase was cleaved by trypsin at the carboxyl terminal region concomitantly with the activation relcasing an oligopeplide. The characteristics of the acely lated aspartase in the present work appear to be somewhat similar to those of the proteinase activated ensyme. Howerer. an attempl to produce further activation by exposing the protcinase activated aspartase to acetylation and vice versa was not successlul. Probably, some kind of indirect conformational change by the modification of amino acid(s) appears to be involycd in the alteration. The molecular basis of the functional alteration is being investigated in order to clarify the relation between the two ensyme types.
Acknowledgment. This research was supported by rescarch grants from Hanyang University (2002) and in part by rescarch grants from Tacgu University (2001).

\section{References}

1. Quastel. I. H.: Woolf, 13. Biocheth. J. 1926. 20. 545.

2. Suzuki. S.: Yamaguchi. T.: Tokushige. M. Biochim Biophns. Actu 1973. 321. 369 .

3. Nuiry. I. I.: Hermes. T. D.: Weiss. P. M.: Chen. C. Y.: Cook. P. F. Biochenistry 1984, 23, 5168 .

4. Yumoto. N.: Tokushige. M. Biochem. Biophls icta 1983. 749. 101

5. Jayasetera. M. M.: Viola. R. E. Bicchem. Bioplns. Res. Commnm. 1999. 264.596 .

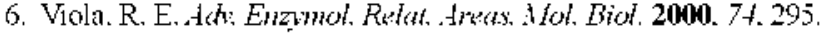

7. Wang. I. I.: Kong. X. 1).: Zhang. II. Y.: Wang. X. P. Zheng. J. Biochen Biophlys Res. Commun 2000. 276.346.

8. Kanata. Y: Famura. K.: Ikei. K.: Mizobata. T.: Natgai, J. Fujita, M.: Yano. S.: Tokushige. M.: Yumoto. N. Eur, J. Biochem. 2000. 267. 1847.

9. Joo. H. S.: Kim. S. S. J. Biocheme. Mol Biol. 2001 . 34. 3.

10. Kim. S. II.: Namgoong. S. K.: Shin. J. II.: Chang S. I.: Choi. J. D). Bull Sorean (hem Soc. 1999, 43. 4.

11. Jo. K.: I long. S.: Choi. M. U.: Chang. S. I.: Choi. J. I.: Koh. I.. I Bull. Korem Chem. Soc: 1997. 18.6

12. Yoon. M. Y.: Park. I. H.: Choi. K. . .: Kim. J. M.: Kim. Y. O.: Park. J. B.: Ky ung. T. B. J. Biochent. Hol Biol 1998. 31. 345.

13. Dawson. R. M. C.: Iflliot I) C.: Elliot. W. II. Iones K.M. Inta for l3icchemical Research, Oxford University Press: I ondon. I ingland. I97I: $p 430$.

14. Cleland. W. W. Methods Enzmol 1979.63.103.

15. Murase. S.: Kawata. Y.: Yumoto. N. J. Biochem. 1993. H4. 393.

16. Choi. H. I.: Kim. S. S. I. Biochem. Mol. Biol 1995. 28. 1.

17. Joo. II. S.: Kim. S. S. J. Biochem Hol Biol. 1988. 37.2.

18. Kim. K. I. J. Biodem. Whot Biol 20MO.33, 172.

19. Shim. I. II: Kim. II. I.: Yoon. M. Y. J. Biochen . Nol. Biol. 1999 32.326.

20. Lec. M. S.: Choi. K. T.: Kwon. S. I.: Kang. I.: Ha. J.: Kim. S. S.: Han. M. S.: Yoon. M. Y. J. Biochm. Hol. Biol 1999. 32. 572. 